Journal of Social Sciences 5(1): 9-15, 2009

ISSN 1549-3652

(C) 2009 Science Publications

\title{
Attitudes of Sultan Qaboos University Students towards Some Environmental Problems and their Willingness to Take Action to Reduce them
}

\author{
Ahmed bin Hamad Al-Rabaani and S.S. Mohammed Al-Mekhlafi \\ Department of Curriculum and Instruction, College of Education \\ Sultan Qaboos University, P.O. Box: 32 Al-Khod, P.C: 123, Muscat, Sultanate of Oman
}

\begin{abstract}
Problem statement: Our earth suffers from many environmental problems which need to be tackled at the individual level, requiring individuals to develop those attitudes which will guide them to environmentally supportive behavior. The objectives of this study were to investigate (i) the attitudes of Sultan Qaboos University students to some environmental problems, (ii) their willingness to take action to ameliorate these problems, (iii) the effect of students' gender and college of study on their attitudes and (iiii) to examine the relationship between students' attitudes and their willingness to take action to reduce these problems. Approach: Data were collected from 317 students from five different faculties. The data were collected by using a questionnaire containing 48 items distributed over 5 dimensions: Energy, water, air pollution, waste and desertification. Validity and reliability were examined. Results: The results showed generally that the students hold positive attitudes towards the issues raised and that female students showed more positive attitudes than males. The results indicated that students' attitudes towards environmental problems did not appear to be influenced by the university faculties in which they are studying, except in the case of energy, where significant differences were observed between the attitudes of students from the faculty of Education and the faculty of Agriculture, the former showing more positive attitudes than the latter. The results showed that students were willing to take action to reduce environmental problems; this was not affected by gender or faculty. Conclusion: The findings suggested the necessity to develop students' attitudes and willingness to take responsibility to reduce these problems.
\end{abstract}

Key words: Environment, attitudes, willingness, environmental problems, environmental education

\section{INTRODUCTION}

Educational concerns about the environment can be viewed as a logical consequence of the change in the relationship between human beings and the natural world over the last two centuries, to the view that earth and its resources are valuable only insofar as they satisfy human needs. Clark $^{[4]}$ explains that this attitude has had a greater negative influence on Nature than natural events such as earthquakes and volcanoes. This change has resulted in the overexploitation of both renewable and non-renewable natural resources with resulting unwanted waste materials, which have lead to pollution Lowe and Thompson ${ }^{[13,19]}$. Dunlop and Van Liere ${ }^{[7]}$ argue that this view has been challenged by the new environmental paradigm of the exploitation of nature; and that the growth of the human economy should be balanced with environmental protection, so that people can again live in harmony with nature.
This challenge contributed to the development of environmental education at the end of the 1960s and later received international acceptance as one of the crucial means of developing people's understanding, awareness, beliefs and attitudes concerning the environment. Since that time various studies have been conducted concerning the effect of environmental education on the development of student attitudes towards the environment. The results of this research are inconsistent: Silberstein ${ }^{[18,5,20,22,23]}$ found that education has a positive effect on student attitudes, while other studies showed no relation between education and attitude Lyons and Breakwell ${ }^{[1,14]}$. Some studies, on the other hand, found that environmental attitudes are influenced by gender Kuhn ${ }^{[11,16,20]}$.

The relationship between attitudes to the environment and willingness to take action was questioned by some researchers. Dunlap et al. ${ }^{[8]}$ in a study which included 24 countries, both rich and poor,

Corresponding Author: Dr. Ahmed bin Hamad Al-Rabaani, Department of Curriculum and Instruction, College of Education, Sultan Qaboos University, P.O. Box: 32 Al-Khod, P.C: 123, Mucat, Sultanate of Oman 
found that $64 \%$ of participants believe that environmental problems will affect their health; 50\% of participants in 21 of these countries said that the environment should be given priority, even if it leads to a slowdown in economic growth; over 50\% of respondents in 17 countries expressed their willingness to pay more to improve the quality of the environment. Inglehart $^{[10]}$ found that $93 \%$ of respondents showed a high level of concern for the protection of the environment. However, $64 \%$ of them expressed their willingness to pay more tax for this purpose and $45 \%$ of them rejected the idea of any sacrifice in order to protect the environment. Thus, people who hold positive attitudes to the environment do not consistently engage in behavior congruent with these attitudes. Some studies concerned about the reasoning behind that, such as Hines et al. ${ }^{[9]}$ concluded that environmental behavior is affected by many components: Knowledge, attitudes, verbal commitment and a sense of personal responsibility.

The present study is concerned with investigating the effect of B.A. level academic courses at Sultan Qaboos University in the Sultanate of Oman on the development of student attitudes towards environmental problems and also on their willingness to take any action that would contribute to reducing them. This university was selected on the basis that it is the only government university in Oman and it is the main source of the development of human resources in this country. The selection of environmental problems was based on their significance for environmental planning in Oman: namely, shortage of water, desertification, air pollution, waste and energy. This study was also concerned with examining the effect of different academic courses taken by students of various university faculties. The following presents the research questions.

This study aimed to answer the following questions:

- What are the attitudes of Sultan Qaboos University students towards environmental problems?

- Are there differences in students' attitudes towards environmental problems that can be attributed to the variables of (a) gender or (b) college?

- Are Sultan Qaboos University students willing to take action to reduce environmental problems?

- Is there any difference between students' willingness to take action that can be attributed to the variable of (a) gender or (b) college?

- Is there a relationship between students' attitudes towards environmental problems and their willingness to take action to reduce them?

\section{MATEIALS AND METHODS}

The population of the study consisted of students in five colleges, namely: Education, arts, science, agriculture and medicine, whose total number in $2002 / 2003$ was 1,700 students. The sample of the study consisted of 311 students drawn mainly from students of the final year in each college. The Table 1 shows the distribution of the sample.

Instrument: In this study, a Likert scale was used because it allows for the use of sub-scales and also facilitates investigating the different dimensions of attitudes. This scale is also a popular technique and students are more likely to be familiar with $\mathrm{it}^{[12,16]}$. The questionnaire consisted of 48 items distributed into five dimensions: Energy problems (13 items), water problems (12 items), air pollution problems (8 items), waste problems ( 8 items) and desertification problems (7 items). The items within each dimension examine two different facets of each area: students' attitudes towards environmental problems and their willingness to take action to reduce those problems. Validity of the questionnaire was examined by a panel of ten experts in the social studies curriculum and psychology departments at the Sultan Qaboos University. Reliability was established by using Cronbach's alpha coefficient for analyzing the results of a pilot study; the results prove that the questionnaire was reliable as the level of reliability reached 0.824 .

Table 1: Distribution of the study sample

\begin{tabular}{llcc}
\hline & & Gender & \\
Faculties & Male & Female & Total \\
\hline Education & 27 & 58 & 85 \\
Arts & 27 & 58 & 85 \\
Science & 28 & 32 & 60 \\
Agriculture & 17 & 36 & 53 \\
Medicine & 17 & 17 & 34 \\
\hline Total & 116 & 201 & 317 \\
\hline
\end{tabular}

\section{RESULTS}

The above results show that students express high levels of concern over environmental problems. It can be observed from Table 2 that water problems come first, with a mean of 3.914, followed by air problems with a mean of 3.910 , waste problems coming third with a mean of 3.790 , then energy problems at a mean of 3.650 and finally desertification at a mean of 3.507. 
Table 2: The means and SD of the students' attitudes

\begin{tabular}{llllc}
\hline Problem & Minimum & Maximum & Mean & SD \\
\hline Energy & 2.38 & 4.62 & 3.6503 & 0.4492 \\
Water & 1.92 & 5.00 & 3.9146 & 0.4822 \\
Air & 1.75 & 5.00 & 3.9101 & 0.5331 \\
Wastes & 2.00 & 5.00 & 3.7906 & 0.5517 \\
Desertification & 1.86 & 4.86 & 3.5074 & 0.5699 \\
\hline
\end{tabular}

Table 3: The means, SD and T-Test results for students attitudes by

\begin{tabular}{|c|c|c|c|c|c|}
\hline \multicolumn{6}{|c|}{ Gender } \\
\hline & \multicolumn{2}{|c|}{ Male } & \multicolumn{2}{|c|}{ Female } & \multirow[t]{2}{*}{$\mathrm{p}<0.05$} \\
\hline & Mean & SD & Mean & SD & \\
\hline Energy & 3.588 & 0.4677 & 3.6862 & 0.4353 & 0.6100 \\
\hline Water & 3.8858 & 0.5544 & 3.9308 & 0.4358 & 0.4250 \\
\hline Air & 3.8222 & 0.5796 & 3.6908 & 0.4988 & $0.260^{*}$ \\
\hline Waste & 3.7985 & 0.5152 & 3.7861 & 0.5729 & 0.8470 \\
\hline Desert & 3.4126 & 0.5670 & 3.5622 & 0.5657 & $0.024 *$ \\
\hline
\end{tabular}

Table 4: Mean scores and standard deviation for students' attitudes by college.

\begin{tabular}{|c|c|c|c|c|c|c|}
\hline College & & Energy & Water & Air & Wastes & Desertification \\
\hline \multirow[t]{2}{*}{ Education } & Mean & 3.75290 & 4.02160 & 3.94850 & 3.72940 & 3.51600 \\
\hline & SD & 0.41256 & 0.40257 & 0.47999 & 0.55227 & 0.53547 \\
\hline \multirow[t]{2}{*}{ Art } & Mean & 3.61900 & 3.83330 & 4.00000 & 3.85440 & 43.56300 \\
\hline & $\mathrm{SD}$ & 0.49196 & 0.57606 & 0.58120 & 0.59225 & 0.61814 \\
\hline \multirow[t]{2}{*}{ Science } & Mean & 3.60260 & 3.87220 & 3.85210 & 3.86250 & 3.48810 \\
\hline & $\mathrm{SD}$ & 0.43356 & 0.39490 & 0.57004 & 0.55555 & 0.47438 \\
\hline \multirow[t]{2}{*}{ Agriculture } & Mean & 3.53120 & 3.87420 & 3.79720 & 3.72640 & 3.39350 \\
\hline & $\mathrm{SD}$ & 0.43704 & 0.45309 & 0.53889 & 0.52409 & 0.62453 \\
\hline \multirow[t]{2}{*}{ Medicine } & Mean & 3.74210 & 3.98530 & 3.86760 & 3.75740 & 3.55880 \\
\hline & $\mathrm{SD}$ & 0.42467 & 0.55636 & 0.42855 & 0.47268 & 0.59825 \\
\hline \multirow[t]{2}{*}{ Total } & Mean & 3.65030 & 3.91430 & 3.91010 & 3.79060 & 3.50740 \\
\hline & $\mathrm{SD}$ & 0.44917 & 0.48221 & 0.53312 & 0.55170 & 0.56987 \\
\hline
\end{tabular}

High concern about the shortage of water could be attributed to the fact that water shortage has become a daily problem that Omani people face in all regions, particularly in interior areas which do not benefit from the desalination plants that have been built in the costal area. Air pollution is a problem which has recently become a cause of concern, due to accelerated economic development and increase in transportation; this may account for students' increasing concern with the problem. The apparently low level of students' concern over desertification could be explained by the fact that Omani students see the desert as a natural phenomenon and that many Omanis do not yet see desertification as a danger to human development. If fact, the desert is often seen as a resource to be developed economically as a tourist attraction. Table 3 indicates that female students hold a statistically significant higher level of concern toward environmental problems than male students, particularly in the areas of desertification (0.24) and air (0.26). These results support the finding of previous literature, which indicates that females are generally more interested in environmental issues than males. ${ }^{[2,3,11,17,21,23]}$.

Table 4 shows the means and SD for students' scores according to college of study.

Table 4 shows that Education and Medicine students hold a higher level of concern toward environmental problems in the areas of energy and water than students from other colleges. In the case of air, waste and desertification problems, higher levels of concern are held by the students of Arts, Education and Medicine. Students from the Science and Agriculture Colleges report average levels of concern and lower levels with respect to desertification problems.

To determine whether the differences in the means are significant, the ANOVA is used, the results are shown in Table 5. Table 5 results show that there are no statistically significant differences in students' attitudes toward environmental problems which can be attributed to the institution of study, except in the case of energy problems, for which differences exist at the level of (0.029). In order to determine the source of these differences, Tukey test was used, the results of which are presented in Table 6.

Table 6 shows differences between the responses of Education students and Agriculture students, where Education students' attitudes are higher than those of Agriculture students. The mean for the former reached (3.7529) whereas that of the latter is (3.5312). This difference may be attributed to the higher academic level of the students accepted in Education (90\%+) and to the fact that Education programs include environmental education. 
Table 5: ANOVA results

\begin{tabular}{|c|c|c|c|c|c|c|}
\hline & & Sum of square & Df & Mean square & $\mathrm{F}$ & Sig \\
\hline \multirow{3}{*}{ Energy } & Between group & 2.154 & 4 & 0.538 & 2.727 & $0.029 *$ \\
\hline & Within group & 61.601 & 312 & 0.197 & & \\
\hline & Total & 63.755 & 316 & & & \\
\hline \multirow[t]{3}{*}{ Water } & Between group & 1.899 & 4 & 0.475 & 2.068 & 0.085 \\
\hline & Within group & 71.579 & 312 & 0.229 & & \\
\hline & Total & 73.477 & 316 & & & \\
\hline \multirow[t]{3}{*}{ Air } & Between group & 1.752 & 4 & 0.438 & 1.552 & 0.187 \\
\hline & Within group & 88.061 & 312 & 0.282 & & \\
\hline & Total & 88.813 & 316 & & & \\
\hline \multirow[t]{3}{*}{ Waste } & Between group & 1.230 & 4 & 0.308 & 1.011 & 0.402 \\
\hline & Within group & 94.950 & 312 & 0.304 & & \\
\hline & Total & 96.180 & 316 & & & \\
\hline \multirow[t]{3}{*}{ Desertification } & Between group & 1.069 & 4 & 0.267 & 0.821 & 0.513 \\
\hline & Within group & 101.552 & 312 & 0.325 & & \\
\hline & Total & 102.620 & 316 & & & \\
\hline
\end{tabular}

$*: \mathrm{p}<0.05$

Table 6: Tukey test results

\begin{tabular}{|c|c|c|c|c|c|}
\hline & Education & Arts & Science & Agriculture & Medicine \\
\hline $\begin{array}{l}\text { Education } \\
\text { Art }\end{array}$ & - & & & * & \\
\hline Science & & & 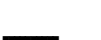 & & \\
\hline Agriculture & * & & & - & \\
\hline Medicine & & & & & - \\
\hline
\end{tabular}

Table 7: Mean scores and SD of students' willingness to take action to reduce environmental problems

\begin{tabular}{lcc}
\hline Environmental problems & Mean & Std. Deviation \\
\hline Water & 3.6183 & 0.62753 \\
Waste & 3.4953 & 0.72956 \\
Air & 303375 & 0.89987 \\
Desertification & 2.9989 & 0.92910 \\
Energy & 2.9411 & 0.87353 \\
\hline
\end{tabular}

Table 8: Mean scores, standard deviation and T-test results

\begin{tabular}{|c|c|c|c|c|c|}
\hline & \multicolumn{2}{|c|}{ Male } & \multicolumn{2}{|c|}{ Female } & \multirow[t]{2}{*}{$\mathrm{p}<0.05$} \\
\hline & Mean & SD & Mean & SD & \\
\hline Energy & 2.8994 & 0.8882 & 2.9652 & 0.8663 & 0.519 \\
\hline Water & 3.5841 & 0.7132 & 3.6381 & 0.5733 & 0.461 \\
\hline Air & 3.2974 & 0.9623 & 3.3607 & 0.8634 & 0.547 \\
\hline Waste & 3.4224 & 0.7507 & 3.5373 & 0.7158 & 0.177 \\
\hline Desert & 2.8670 & 0.9699 & 3.0740 & 0.8984 & 0.056 \\
\hline
\end{tabular}

Table 7 shows the mean scores and standard deviation of students' willingness to take part in reducing environmental problems.

It can be seen from Table 7 that students hold a high level of positive attitudes toward environmental problems, particularly the problems connected with water (3.618) and waste (3.495). This high level of positive attitudes may be attributed to students' realization of the seriousness of these problems and the importance of individuals' participation in confronting them. Students may have realized too that the country is facing serious problems in the area of water. However, Table 8 indicates a low level of students' willingness to participate in programs aimed at reducing energy and desertification problems, with a mean of (2.941) and (2.998) respectively. This result, in the case of the former, may be attributed to the fact that people feel that they can live without air-conditioning despite the extremely hot weather, or to the fact that the cost of electricity in Oman is relatively low; in either case, this aspect of energy conservation is not a priority. In the case of problems arising out of desertification, the suggested explanation given above for the low level of student concern over problems of desertification also applies to their apparent lack of enthusiasm for participation in programs aimed at tackling desertification.

There are no statistically significant differences in students' willingness to participate in reducing environmental problems that can be attributed to the variable of gender, though female students' level is higher (.056) than male students.

The results presented in Table 9 shows no statistically significant differences between students' attitudes towards environmental problems and their willingness to participate in programs aimed at dealing with those problems, which can be attributed to the variable of college of study. This convergence of results, in particular in the areas of air (0.782) and waste (0.730), may be attributed to the fact that all students live in the same urban environment where air pollution is becoming increasingly a matter of concern. 
Table 9: 2-Way ANOVA results

\begin{tabular}{|c|c|c|c|c|c|c|}
\hline & & Sum of square & Df & Mean square & $\mathrm{F}$ & Sig \\
\hline \multirow{3}{*}{ Energy } & Between group & 3.532 & 4 & 883.000 & 1.159 & 0.329 \\
\hline & Within group & 237.591 & 312 & 762.000 & & \\
\hline & Total & 241.123 & 316 & & & \\
\hline \multirow[t]{3}{*}{ Water } & Between group & 1.934 & 4 & 483.000 & 1.231 & 0.297 \\
\hline & Within group & 122.505 & 312 & 393.000 & & \\
\hline & Total & 124.439 & 316 & & & \\
\hline \multirow[t]{3}{*}{ Air } & Between group & 1.424 & 4 & 356.000 & 436.000 & 0.782 \\
\hline & Within group & 254.459 & 312 & 816.000 & & \\
\hline & Total & 255.883 & 316 & & & \\
\hline \multirow[t]{3}{*}{ Waste } & Between group & 1.087 & 4 & 272.000 & 507.000 & 0.730 \\
\hline & Within group & 167.156 & 312 & 536.000 & & \\
\hline & Total & 168.243 & 316 & & & \\
\hline \multirow[t]{3}{*}{ Desertification } & Between group & 1.626 & 4 & 0.407 & 0.680 & 759.000 \\
\hline & Within group & 271.151 & 312 & 0.869 & & \\
\hline & Total & 272.77 & 316 & & & \\
\hline
\end{tabular}

Table 10: Correlation scale between students' attitudes towards environmental problems and their willingness to take part in reducing them.

\begin{tabular}{lcc}
\hline Attitudes & Pearson correlation coefficient & Sig. \\
\hline Contribution & 0.340 & 0.01 \\
\hline
\end{tabular}

Table 11: Correlation coefficient of students' attitudes and their willingness to participate in reducing them

\begin{tabular}{lllllll}
\hline $\begin{array}{l}\text { Willing to } \\
\text { contribution }\end{array}$ & Energy Water & Air & Wastes Desertification \\
\hline Attitudes & $\begin{array}{l}\text { Pearson } \\
\text { correlation }\end{array}$ & 0.347 & 0.475 & 0.324 & 0.335 & 0.330 \\
& & & & & \\
coefficient & & & & & \\
Sig. & 0.000 & 0.000 & 0.000 & 0.000 & 0.018 \\
N & 0.317 & 0.317 & 0.317 & 0.317 & 0.317 \\
\hline
\end{tabular}

Table 10 shows a correlation between students' attitudes towards environmental problems and their willingness to participate in reducing those problems. More information on this positive relation and its scale in each area is presented in the Table 11.

The results indicate the existence of a correlation between students' attitudes towards environmental problems and their willingness to participate in facing those problems.

\section{DISCUSSION}

The results of the study show that students have positive attitudes towards reducing environmental problems. These results support the findings of previous studies that showed relationship between education and people attitudes towards the environment ${ }^{[5,19,21,23,25]}$. Students' attitudes were affected by their course of study, which supports the idea that education plays, or can play, a role in developing people's attitudes towards the environment, although the results of some studies suggest that there is no relation between education and attitude to the environment ${ }^{[1,14]}$. The results also suggest that the students' attitudes reflect the growing urgency of the increase in certain environmental problem in Oman. For example, the high level of concern they express over the issue of the availability of water reflects the dangers of desertification and the need for serious planning to prepare for the possibility of serious drought in the future. Already in some areas, farms are disappearing and some regions have reported difficulty in finding clean drinking water during the dry seasons. The lower level of concern shown by the students over the issue of energy use reflects the comparatively easy and cheap availability of energy in Oman.

The results also indicate that students' attitudes towards the environment reflect differences which may be attributed to gender: Females had a higher level of positive attitudes to environmental problems than males. This is in agreement with the results of several other studies ${ }^{[11,17,21]}$. According to the literature, the higher level of concern shown by females may be attributed to their nature and upbringing as future nurturers. It may also reflect the attempts by females in a developing society to reduce the gender gap by proving themselves involved in social concerns.

Despite the high level of concern expressed by the students over environmental problems, their willingness to act towards the alleviation of those problems varied. This result supports the findings of previous studies ${ }^{[8,10,15]}$.This results support the findings of Hines et al. ${ }^{[9]}$ that the level of consistency between environmental attitudes and behavior is affected by a person's knowledge and awareness, public verbal commitment and his/her sense of responsibility. The transfer from attitudes to behavior can also be affected by lifestyle; many people, while professing to "correct" attitudes to 
the environment, are not ready to change their lifestyle in ways that might mean sacrificing certain forms of leisure and comfort for the sake of the environment: other study ${ }^{[6]}$ has also found a weak and inconsistent relationship between environmental attitudes and behavior, usually attributable to a reluctance to give up the comforts of modern life.

\section{CONCLUSION}

The results of the study support the findings of the literature, which indicates that students are developing more positive attitudes about the need to reduce environmental problems. This is promising, showing that young people are becoming more aware of and are showing more understanding of the danger facing our planetary environment and their own role in controlling environmental degradation and its outcomes. However, it is apparent that the Omani educational system needs to put more effort into raising students' awareness of the importance of their individual and community role in tackling environmental problems, in order to give future generations the chance to live in a healthy environment.

\section{ACKNOWLEDGMENT}

Researchers owe a debt of gratitude to Sultan Qaboos University administration and students for their cooperation during conducting this research.

\section{REFERENCES}

1. Al-Najede, A., 1990. The effect of environmental science curriculum on development of environmental attitudes of in service teachers. Egyptian Associat. Curr. Teach. Methods, 1: 40-45.

2. Bissonnette, M.M., 1999. Adolescents' Perspectives about the Environmental Impact of Food Production Practices. http://academiccommons.columbia.edu:8080/ac/ha ndle/10022/AC:P:17123

3. Chin, C., 1993. A Study of Environmental Knowledge, Attitudes and Behavior of Secondary Students and Pre-and In-Service Teachers in Taiwan (pre-Service Teacher, China). DIA, 54/08

4. Clark, W., 1989. The Human Ecology of Global Change. Int. Soc. Sci. J., 41: 315-346.

5. Cohen, S. and D. Wingerd, 1993. Children and the environment: Ecological awareness among preschool children. Environ. Behavior, 25: 103-120. DOI: 10.1177/0013916593251005

6. Diekmann, A. and P. Preisendorfer, 1998. Environmental behavior-discrepancies between aspirations and reality. Rationality Soc., 10: 79-102. DOI: $10.1177 / 104346398010001004$

7. Dunlap, R.E. and K.D. Van Liere, 1978. The new environmental paradigm: A proposed measuring instrument and preliminary results. J. Environmental. Edu., 9: 10-19.

8. Dunlap, R.E., G.H. Gallup and A.M. Gallup, 1993. Of global concern: Results of the health planet survey. Environment, 35: 7-39. http://eric.ed.gov/ERICWebPortal/custom/portlets/ recordDetails/detailmini.jsp?_nfpb=true\&_\&ERIC ExtSearch_SearchValue_0=EJ482365\&ERICExtS earch_SearchType_0=no\&accno=EJ482365

9 Hines, J., H. Hugerford and A. Tomera, 1986. Analysis and synthesis of research on responsible environmental behavior. J. Appl. Soc. Psychol., 22: 657-676.

10. Inglehart, R., 1995. Public support for environmental protection: Objective problems and subjective values in 43 societies. Polit. Sci. Polit., 28: 57-72. http://www.jstor.org/pss/420583

11. Kuhn, D., 1979. Study of the attitudes of secondary school students towards energy-related issues. Sci. Edu., 63: 609-620.

12. Likert, R., 1967. The Method of Constructing an Attitude Scale. In: Readings in Attitude Theory and Measurement, Fishbein, M., (Ed.). John Wiley, New York, pp: 90-95.

13. Lowe, M. and D. Thompson, 1992. Pollution and Development. In: Environmental Issues in the 1990s, Mannion, A. and S. Bowlby (Eds). John Wiley, New York, pp: 197-210.

14. Lyons, E. and G. Breakwell, 1994. Factors predicting environmental concern and indifference in 13-to 16 years-olds. Environ. Behavior, 26: 223-238. DOI: 10.1177/001391659402600205

15. Olli, E., G. Grendstad and D. Wollebaek, 2001. Correlates of environmental behaviors: Bringing back social context. Environ. Behav., 33: 181-208. DOI: 10.1177/0013916501332002

16. Oppenheim, A., 1992. Questionnaire Design, Interviewing and Attitudes Measurement. New Edn., Pinter Publication Ltd., London and Washington, pp: 310. ISBN: -10: 1855670445

17. Schahn, J. and E. Holzer, 1990. Studies of individual environmental concern: The role of knowledge, gender and background variables. Environ. Behavior, 122: 767-786. DOI: 10.1177/0013916590226003 
18. Silberstein, M., 1981. Factors which affect students attitudes towards the use of living animals in learning biology. J. Sci. Edu., 65: 119-130.

19. Soussan, J., 1992. Sustainable Development. In: Environmental Issues in the 1990s, Mannion, A. and S. Bowlby (Eds.). John Wiley, New York, pp: 21-36.

22. Stoney, S., 1995. Environmental Education: Teaching Approaches and Students Attitudes. www.susx.ac.uk./Units/gec/

21. Stepaniak, L., R. Tobiassen, I. Chukwu, A. Pripp, T. Sorhaug, A. Worsley and G. Skrzpiec, 1998. Environmental attitudes of senior secondary school students in South Australia. Global Environ. Change, 8: 209-225. DOI: 10.1016/S09593780(98)00016-8
22. Surbrook, N., 1997. Children's exposure to the natural environment and their environmental attitudes: An exploratory Study. DIA, 36/01.

23. Zelezny, L., 1998. School Recycling and Students' Environmental Attitudes and Behaviors. DAI, $59 / 01$. 